\title{
Tilapia is the Fish for Next - Generation Aquaculture
}

Review Article

\author{
G.H. Yue ${ }^{1,2^{*}}$, H.R. $\operatorname{Lin}^{3}$, J.L. Li ${ }^{4}$
}

${ }^{1}$ Temasek Life Sciences Laboratory, 1 Research Link, National University of Singapore, 117604 Republic of Singapore.

${ }^{2}$ Department of Biological Sciences, National University of Singapore, 14 Science Drive 4, Singapore 117543.

${ }^{3}$ Institute of Aquatic Economic Animals, Sun Yat-sen University, Guangzhou, China.

${ }^{4}$ College of Aqua-Life Science and Technology, Shanghai Ocean University, Shanghai 200090, China.

\section{Abstract}

Fish is one of the major sources of animal protein supply for humans, but wild fish stocks are being depleted rapidly due to overfishing. Therefore, future fish supply will depend on sustainable aquaculture, which should add edible protein to the world, rather than reduce it. Tilapias, having unique characteristics, are suitable species for future sustainable aquaculture. Land-based recirculating aquaculture, and cage and offshore aquaculture will reduce the negative impacts of tilapia culture on the environment and global biodiversity. Further genetic improvement of tilapias will be accelerated by using contemporary molecular techniques.

Keywords: Aquaculture; Food; Tilapia; Environment; Recirculating; Land-based.

\section{Next-generation sustainable aquaculture}

The world population will be 9.3 billion by 2050 . Meeting basic human needs for animal protein is a challenge in an increasingly over populated world. Besides livestock, fish is the major source of animal protein supply. The wild fish resource is limited for fisheries [7]. Depleting wild stocks is an increasing concern for fishermen, environmental organizations and policy-makers. Sustainable aquaculture can play an important role in the transition to a more environmentally and economically viable fish production [3]. Land-based recirculating aquaculture [13], and cage and offshore aquaculture [8] offer a unique combination of protection of wild stocks, socioeconomic benefits, and potential for sustainability and scalability. Such technology could change the way of fish production, leading to the large-scale culture of fish just as has been done with livestock, and thus will be the future of aquaculture. However, aquaculture faces a unique challenge, namely, reliance on wild-caught fish as feed for farming carnivorous fish, which could further contribute to the depletion of fish stocks [2, 15]. Future aquaculture should add edible protein to the world, rather than reduce it. Therefore, selection of species for aquaculture is critical to ensure sustainable fish supply while conserving wild fish stocks. Fish that do not need fish protein or less fish protein in their feeds will be the future of aquaculture.

\section{Tilapia is the fish for next-generation aquaculture}

Among the 420 cultured fish species, carps, catfishes and tilapias require less fish meals in their feeds than other species [10]. However, carpsare unfamiliar to the Western diet while most cultured catfishes cannot be cultured in seawater. Tilapias have gained widespread popularity, and certain tilapia hybrids can grow in brackish water and seawater $[9,12]$. Therefore, tilapias are the fish for future aquaculture. Tilapias originate from Africa and the Middle East [12]. Tilapias are hardy, prolific and fastgrowing tropical fishes. They are low on the food chain, adaptable and herbivorous, feeding mainly on plankton, algae, aquatic macrophytes and other vegetable matter $[16,19]$. Thus, tilapias help to ease the fishing pressure on wild fish stocks [6]. Their mild-tasting flesh can be easily adapted to all kinds of uses. The production performances of several breeds and strains have been substantially improved through breeding [4, 9, 17, 18]. Farmed tilapias reach market size (i.e. 600-900 g) in 6-9 months of culture. Tilapias have been farmed in at least 120 countries $[9,12]$. The

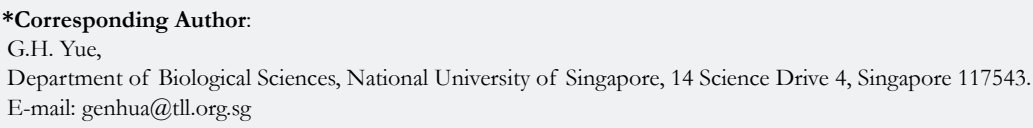

Copyright: G.H. Yue ${ }^{\circ}$ 2016. This is an open-access article distributed under the terms of the Creative Commons Attribution License, which permits unrestricted use, distribution and reproduction in any medium, provided the original author and source are credited. 
major producers are developing countries, including China, Indonesia, Philippines, Thailand, Honduras, Ecuador and Costa Rica. The global tilapia production increased rapidly and was 5.6 million tons in 2015 (Figure 1) [9]. In addition, culturing of tilapias has improved the livelihoods of people in developing countries and delivered a wide range of benefits, such as higher household incomes, and improved food security and higher nutritional value through increased protein consumption. Therefore, the culture of tilapias should be promoted. Exchange of genetic resources from different countries may accelerate genetic improvement tilapia [5].

\section{Some challenges of tilapia aquaculture}

Although culturing tilapias holds great promise, there are a few challenges. First, farmed tilapias contain small amounts of beneficial omega-3 fatty acids compared with other fish (e.g. salmon) [22]. Second, most tilapia species are not tolerant to high salinity although some (e.g. Mozambique tilapia) can grow in seawater $[6,12]$. Third, the limited ability of tilapias to tolerate low temperatures $\left(<15^{\circ} \mathrm{C}\right)[6,12]$ restricts the geographical scope of tilapia culture. More research will be required to improve the essential fatty acid content and tolerance to high salinity and cold. Probably, selective breeding [10] and improved feeds incorporating marine microalgae containing high percentage of omega-3 [21] can improve the essential fatty acid content of tilapias. Crossing the quick growing Nile tilapia with the salttolerant Mozambique tilapia is a way to improve salinity tolerance. With the rapid development of next-generation sequencing technologies [14], marker-assisted selection and genomic selection will substantially accelerate the genetic improvement of tilapias $[20,23]$. Another concern of tilapia aquaculture is its negative impacts on the environment and global biodiversity. Therefore, proper monitoring measures and certification of tilapia farms are essential to protect the environment and aquatic biodiversity [1]. Land based recirculating aquaculture, and cage and offshore culture (Figure 1) can reduce negative impacts of tilapia culture on the environment and global biodiversity [11,13], and are thus likely to grow in production and technological advances. These systems facilitate aquaculture almost anywhere, and thus will be the key parts of next-generation aquaculture.

Figure 1. Main cultured tilapia species (A), Global aquaculture production of tilapia (B), Future aquaculture systems (C).
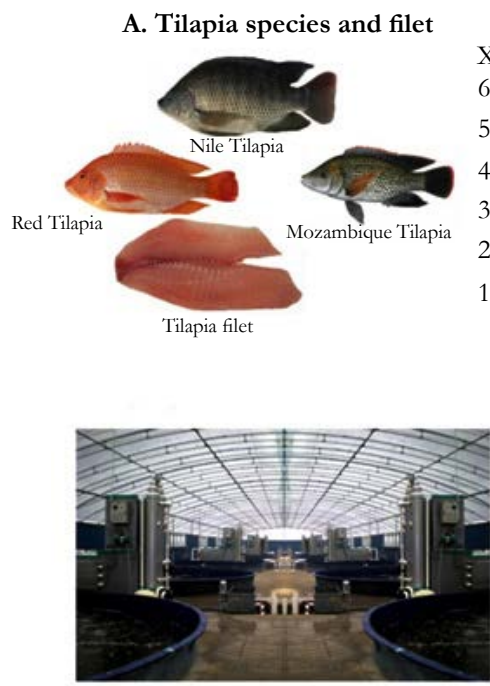

C. Land based recycling aquaculture
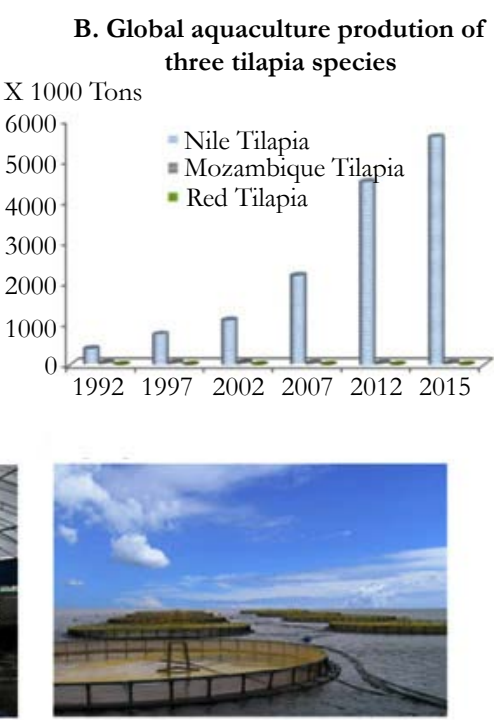

Cage aquaculture

\section{References}

[1]. Bush SR, Belton B, Hall D, Vandergeest P, Murray FJ, et al. (2013) Certify Sustainable Aquaculture? Science 341: 1067-1068.

[2]. Cao L, Naylor R, Henriksson P, Leadbitter D, Metian M, et al. (2015) China's aquaculture and the world's wild fisheries. Science 347(6218): 133-135.

[3]. Cressey D (2009) Aquaculture: future fish. Nature 458: 398-400.

[4]. Dey MM (2000) The impact of genetically improved farmed Nile tilapia in Asia. Aquaculture Economics \& Management 4(1-2): 107-124.

[5]. Eknath AE, Hulata G (2009) Use and exchange of genetic resources of Nile tilapia (Oreochromis niloticus). Reviews in Aquaculture 1(3-4): 197-213.

[6]. El-Sayed AFM (2006) Tilapia culture. CABI Publishing, UK.

[7]. FAO (2014) The State of World Fisheries and Aquaculture. FAO, Rome.

[8]. Ferreira JG, Sequeira A, Hawkins AJS, Newton A, Nickell TD, et al. (2009) Analysis of coastal and offshore aquaculture: application of the FARM model to multiple systems and shellfish species. Aquaculture 289(1): 32-41.

[9]. Fitzsimmons KM (2016) Global Tilapia Market update 2015. In: WAS 2016, Las Vegas.

[10]. Gjedrem T, Baranski M (2009) Selective breeding in aquaculture: an introduction. Springer, London.

[11]. Halwart M, Soto D, Arthur JR (2007) Cage aquaculture, Regional reviews and global overview. FAO, Rome, Italy.
[12]. Lim C, Webster CD (2006) Tilapia: biology, culture, and nutrition. CRC Press. New York

[13]. Martins CIM, Eding EH, Verdegem MCI, Heinsbroek LTN, Schneider O, et al. (2010) New developments in recirculating aquaculture systems in Europe: A perspective on environmental sustainability. Aquacultural Engineering 43(3): 83-93.

[14]. Metzker ML (2010) Sequencing technologies - the next generation. Nat Rev Genet 11(1): 31-46

[15]. Naylor RL, Goldburg RJ, Primavera JH, Kautsky N, Beveridge MCM, et al. (2000) Effect of aquaculture on world fish supplies. Nature 405: 1017-1024.

[16]. Ng WK, Romano N (2013) A review of the nutrition and feeding management of farmed tilapia throughout the culture cycle. Reviews in Aquaculture 5(4): 220-254

[17]. Nguyen NH (2015) Genetic improvement for important farmed aquaculture species with a reference to carp, tilapia and prawns in Asia: achievements, lessons and challenges. Fish and Fisheries, in press.

[18]. Ponzoni RW, Nguyen HN, Khaw HL, Hamzah A, Abu Bakar KR, et al. (2011) Genetic improvement of Nile tilapia (Oreochromis niloticus) with special reference to the work conducted by the WorldFish Center with the GIFT strain. Reviews in Aquaculture 3(1): 27-41.

[19]. Saikia SK, Das DN (2015) Sustainable aquaculture: agro-ecological role of periphyton in ricefish farming. Reviews in Aquaculture 7(3): 172-186. 
[20]. Sonesson AK, Liu Z (2010) Genomic Selection for Aquaculture: Principles and Procedures. Next Generation Sequencing and Whole Genome Selection in Aquaculture. 151-163.

[21]. Tadesse Z, Boberg M, Sonesten L, Ahlgren G (2003) Effects of algal diets and temperature on the growth and fatty acid content of the cichlid fish Oreochromis niloticus L.-A laboratory study. Aquatic Ecology 37: 169-182.
[22]. Weaver KL, Ivester P, Chilton JA, Wilson MD, Pandey P, et al. (2008) The content of favorable and unfavorable polyunsaturated fatty acids found in commonly eaten fish. J Am Diet Assoc 108(7): 1178-1185.

[23]. Yue GH (2014) Recent advances of genome mapping and marker-assisted selection in aquaculture. Fish and Fisheries 15(3): 376-396. 